\title{
Index Evaluation System on the Degree of Production-City Integration in New Urban Development Zones: a case study of the Dajiangdong new town in Hangzhou
}

\author{
JIANG ShangKun ${ }^{1,}$; XU Zheng ${ }^{2, b}$ \\ ${ }^{1,2}$ Economics and Management School of Hangzhou Normal \\ University,HangZhou,ZheJiang,311121 China \\ a,b891819695@qq.com
}

Keywords: new town construction; production-city integration; index system

\begin{abstract}
According to effect factors of production-city integration in new town construction, this paper combines with construction principle of production-city integration evaluation index system and chooses index of evaluating new production-city integration degree from perspectives of industrialization and urbanization, it puts forward problems of applying proper methods to make standardized processing on index weight, quantitative index and pointedly adopts measures etc, and it also gives corresponding solution methods.
\end{abstract}

\section{Introduction}

With the advancement of industrialization and urbanization as well as development and enlargement of industrial zone, plenty of city new towns are appearing one after another. Affected by traditional development way, new town construction appears situation of life function lags behind production function; public service constriction falls behind economic construction, it accompanies with plenty of empty cities and sleep cities. Under this background, idea of production-city integration appears as times requires. On this basis, development and construction strength of Dajiangdong new town in Hangzhou is obviously accelerating; it relies on idea of production-city integration, its overall thinking and strategic key point becomes increasingly clear, system and mechanism is stable and innovative during exploration, effect of resources integration and environment optimization begins to appear, new town development and construction presents good development trend.

\section{Evaluation index system and model of Dajiangdong new town in Hangzhou}

A. Construction principle. Evaluation index system construction of Dajiangdong new town in Hangzhou needs to follow the following principles: the first one is systematic principle, which means all indexes in index system can construct one system, making evaluation target and evaluation index connect into one organized whole. The second one is scientific principle; every index should be constructed on the basis of scientific analysis, which can objectively reflect development state of industry and city. Every index should have clear concept, definite connotation, guarantee the authenticity and objectivity of city development. The third one is principle of combining with hierarchy and integrity. Production-city integration evaluation index system needs to completely reflect overall characteristics of city development, it should not only reflect development trend of mutual coordination and interaction in every subsystem, but also should reflect development state within system. Construction of index system should include 3 levels: target level, criterion level and index level. The fourth one is principle of combining with stability and dynamics. City development is always in the planning and construction without stop, it makes evaluation on different stage of city construction. 
B. Evaluation index system of production-city integration

Production-city integration development in city involves with plenty of factors, this paper makes analysis on production-city separation causes and constructs production-city integration evaluation index system of III grade.

Tab.1The assessment index system of industry and city fusion

\begin{tabular}{|c|c|c|c|c|}
\hline $\begin{array}{l}\text { Target } \\
\text { level A }\end{array}$ & $\begin{array}{c}\text { I-grade index } \\
\text { B } \\
\end{array}$ & $\begin{array}{l}\text { II-grade } \\
\text { index C }\end{array}$ & III-grade index D & $\begin{array}{c}\text { Index } \\
\text { category }\end{array}$ \\
\hline \multirow{22}{*}{$\begin{array}{c}\text { Evaluatio } \\
\text { n index } \\
\text { system A } \\
\text { of } \\
\text { productio } \\
\text { n-city } \\
\text { integratio } \\
\text { n }\end{array}$} & \multirow{9}{*}{$\begin{array}{c}\text { Economic } \\
\text { development } \\
\mathrm{B}_{1}\end{array}$} & \multirow{3}{*}{$\begin{array}{l}\text { economic } \\
\text { aggregate }_{1}\end{array}$} & GDP of unit area $D_{1}\left(10000\right.$ Yuan $\left.\cdot / \mathrm{km}^{-2}\right)$ & Positive \\
\hline & & & $\begin{array}{l}\text { amount of fixed asset investment per unit } \\
\text { area } D_{2}\left(10000 \text { Yuan } \cdot / \mathrm{km}^{-2}\right)\end{array}$ & Positive \\
\hline & & & per capita income $\mathrm{D}_{3}($ Yuan $\bullet$ person/-1) & Positive \\
\hline & & \multirow{3}{*}{$\begin{array}{l}\text { Economic } \\
\text { structure } \mathrm{C}_{2}\end{array}$} & $\begin{array}{l}\text { Gross industrial output per unit area } \mathrm{D}_{4} \\
\left(100 \text { million Yuan } \bullet / \mathrm{km}^{-2}\right)\end{array}$ & Positive \\
\hline & & & secondary industry proportion $\mathrm{D}_{5} / \%$ & Positive \\
\hline & & & proportion of the tertiary industry $\mathrm{D}_{6} / \%$ & Positive \\
\hline & & \multirow{3}{*}{$\begin{array}{l}\text { economic } \\
\text { benefit } C_{3}\end{array}$} & Per capita GDPD $7\left(\right.$ Yuan $•$ person $\left.{ }^{-1}\right)$ & Positive \\
\hline & & & GDP growth rate $\mathrm{D}_{8} / \%$ & Positive \\
\hline & & & average salary of staff $\mathrm{D}_{9} /$ Yuan & Positive \\
\hline & \multirow{5}{*}{$\begin{array}{l}\text { Urbanization } \\
\text { levelB }_{2}\end{array}$} & \multirow{2}{*}{$\begin{array}{l}\text { population } \\
\text { state } \mathrm{C}_{4}\end{array}$} & density of population $\mathrm{D}_{10}\left(\right.$ person $\left.\cdot / \mathrm{km}^{-2}\right)$ & negative \\
\hline & & & natural population growth rate $\mathrm{D}_{11 /} \%$ & negative \\
\hline & & \multirow{3}{*}{$\begin{array}{l}\text { Living } \\
\text { standard } \mathrm{C}_{5}\end{array}$} & per capita disposable income $\mathrm{D}_{12} /$ Yuan & Positive \\
\hline & & & $\begin{array}{l}\text { Per capita year-end savings balance } \\
\mathrm{D}_{13} / \text { Yuan }\end{array}$ & Positive \\
\hline & & & consumer price index $\mathrm{D}_{14 /} \%$ & negative \\
\hline & \multirow{8}{*}{$\begin{array}{c}\text { Matching } \\
\text { construction } \\
\mathrm{B}_{3}\end{array}$} & \multirow{4}{*}{$\begin{array}{l}\text { Public } \\
\text { service } C_{6}\end{array}$} & $\begin{array}{l}\text { Number of schools per } 10,000 \mathrm{D}_{15} \\
\left(\text { one } \cdot 10000 \text { persons }{ }^{-1}\right)\end{array}$ & Positive \\
\hline & & & $\begin{array}{l}\text { Number of hospital beds per } 10,000 \text { people } \\
\mathrm{D}_{16} / \text { bed }\end{array}$ & Positive \\
\hline & & & $\begin{array}{l}\text { Number of institutions with cultural } \\
\text { activities per } 10,000 \text { population } \mathrm{D}_{17} \\
\quad\left(\text { institute } \cdot 10000 \text { persons } /^{-1}\right)\end{array}$ & Positive \\
\hline & & & $\begin{array}{l}\text { Number of public transport vehicles per } \\
10,000 \text { population } D_{18} \quad \text { (vehicle } \cdot 10000 \\
\left.\text { persons } /^{-1}\right)\end{array}$ & Positive \\
\hline & & \multirow{4}{*}{$\begin{array}{l}\text { Environment } \\
\text { state } \mathrm{C}_{7}\end{array}$} & $\begin{array}{l}\text { green coverage rate of developed areas } \\
\mathrm{D}_{19 / \%}\end{array}$ & Positive \\
\hline & & & $\begin{array}{l}\text { per capita green area } \mathrm{D}_{20}(/ \mathrm{hm} 2 \cdot 10000 \\
\left.\text { persons }^{-1}\right)\end{array}$ & Positive \\
\hline & & & sewage treatment rate $\mathrm{D}_{21} / \%$ & Positive \\
\hline & & & $\begin{array}{l}\text { Harmless disposal rate of domestic waste } \\
\mathrm{D}_{22} / \%\end{array}$ & Positive \\
\hline
\end{tabular}

C. Production-city integration evaluation model based on AHP

(1) Confirm weight index

Establish evaluation index system, please see table 1, construct comparative judgment, after establishing evaluation index system, it needs to make comparison and mark on index on every level, it will get relative importance judgment of index, finally it forms one comparative matrix $A=(a i j)_{\mathrm{nxn}}$. The comparison scale of marks refers to quartile scaling method put forward by Suttie(table 2). 
Tab. 2 The comparative value of assessment index

\begin{tabular}{|c|c|}
\hline scale & Meaning \\
\hline 1 & $\begin{array}{l}2 \text { elements compare with each other, both have the same } \\
\text { importance }\end{array}$ \\
\hline 3 & $\begin{array}{l}2 \text { elements compare with each other, the former is more } \\
\text { important than the latter }\end{array}$ \\
\hline 5 & $\begin{array}{l}2 \text { elements compare with each other, the former is } \\
\text { obviously more important than the latter }\end{array}$ \\
\hline 7 & $\begin{array}{l}2 \text { elements compare with each other, the former is rather } \\
\text { important than the latter }\end{array}$ \\
\hline 9 & $\begin{array}{l}2 \text { elements compare with each other, the former is } \\
\text { extremely important than the latter }\end{array}$ \\
\hline $2, \quad 4,6, \quad 8$ & median of the above-mentioned adjacent scale judgment \\
\hline Count backwards & $\begin{array}{l}2 \text { elements compare with each other, importance of the } \\
\text { latter relative to the former }\end{array}$ \\
\hline
\end{tabular}

Level single sequence, as for certain element the above level, it calculates every factor weight related to in the next level. It starts from judgment matrix and uses square root method to calculate judgment the maximum characteristic root and characteristic vector.

(1) Step 1: according to formula: $W i=\frac{\left[\prod_{j=1}^{n} a_{i j}\right]^{\frac{1}{n}}}{1}(i=1,2, \ldots . k)$, it gets characteristic vector of $\sum_{i=1}^{n}\left[\prod_{j=1}^{n} a_{i j}\right]^{\frac{1}{n}}$

judgment matrix $B=\left(W_{1}, W_{2}, \cdots, W_{n}\right)^{\mathrm{T}}$ 。(2)step 2: according to formula $\lambda_{\max }=\sum_{i=1}^{n} \frac{\sum_{j=1}^{n} a_{i j} w_{j}}{n w_{i}}$, it gets the maximum characteristic root of judgment matrix(3)step 3: it calculates consistency index of judgment matrix, formula is as follows: $C I=\frac{\lambda_{\max }-n}{n-1} n-1$. Of which, $\lambda_{\max }$ is the maximum characteristic root of judgment matrix; $n$ is order of judgment matrix (4)step 4: it makes comparison and calculation according to average random value RI(table 3 ) to confirm random consistency ratio. The calculation formula of random consistency is as follows: $\mathrm{CR}=\mathrm{CI} / \mathrm{RI}$. Of which: $\mathrm{CR}$ is random consistency ratio; $\mathrm{CI}$ is consistency index; $\mathrm{RI}$ is average consistency index.

Table 3 Comparison table of average consistency index

\begin{tabular}{|c|c|c|c|c|c|c|c|c|c|c|c|c|}
\hline$n$ & 1 & 2 & 3 & 4 & 5 & 6 & 7 & 8 & 9 & 10 & 11 & 12 \\
\hline$R I$ & 0 & 0 & 0.58 & 0.89 & 1.12 & 1.26 & 1.36 & 1.41 & 1.46 & 1.49 & 1.52 & 1.54 \\
\hline
\end{tabular}

If $C R$ is less than 0.1, we think judgment matrix passes through consistency test, if $C R$ is bigger than 0.1 , we think judgment matrix dose not have satisfied consistency, it needs to make adjustment. According to the above designed calculation methods, it can get weight value of every level index in index system for the above level index. 4) Total sequence of level. In certain level index sequence result, calculates combination weight of this level for the above level, especially for final weight of the bottom index for target level, it needs to calculate level by level from index system and finally gets the final index weight set (table 4). 
Table 4 Evaluation index weight and sequence of production-city integration

\begin{tabular}{|c|c|c|c|c|c|}
\hline $\begin{array}{l}\text { Target } \\
\text { level A }\end{array}$ & $\begin{array}{l}\text { I-grade } \\
\text { index B } \\
\text { and } \\
\text { weight }\end{array}$ & $\begin{array}{l}\text { II-grade } \\
\text { index C } \\
\text { and weight }\end{array}$ & III-grade index D & $\begin{array}{l}\text { III-gra } \\
\text { de } \\
\text { index } \\
\text { weight }\end{array}$ & $\begin{array}{l}\text { sequ } \\
\text { ence }\end{array}$ \\
\hline \multirow{22}{*}{$\begin{array}{c}\text { Evaluati } \\
\text { on index } \\
\text { system A } \\
\text { of } \\
\text { producti } \\
\text { on-city } \\
\text { integrati } \\
\text { on }\end{array}$} & \multirow{9}{*}{$\begin{array}{c}\text { Economic } \\
\text { developm } \\
\text { ent } \mathrm{B}_{1} \\
0.5842\end{array}$} & \multirow{3}{*}{$\begin{array}{c}\text { economic } \\
\text { aggregateC } \\
1 \\
0.3397\end{array}$} & GDP of unit area $\mathrm{D}_{1}\left(10000\right.$ Yuan $\left.\cdot / \mathrm{km}^{-2}\right)$ & 0.1676 & 1 \\
\hline & & & $\begin{array}{l}\text { amount of fixed asset investment per unit } \\
\text { area } D_{2}\left(10000 \text { Yuan } \cdot / \mathrm{km}^{-2}\right)\end{array}$ & 0.1056 & 3 \\
\hline & & & per capita income $\mathrm{D}_{3}($ Yuan $\bullet$ person/-1) & 0.0665 & 5 \\
\hline & & \multirow{3}{*}{$\begin{array}{c}\text { Economic } \\
\text { structure } \\
\mathrm{C}_{2} \\
0.0640\end{array}$} & $\begin{array}{l}\text { Gross industrial output per unit area } \mathrm{D}_{4} \\
\left(100 \text { million Yuan } \bullet / \mathrm{km}^{-2}\right)\end{array}$ & 0.0210 & 15 \\
\hline & & & secondary industry proportion $\mathrm{D}_{5} / \%$ & 0.0166 & 18 \\
\hline & & & proportion of the tertiary industry $\mathrm{D}_{6} / \%$ & 0.0264 & 12 \\
\hline & & \multirow{3}{*}{$\begin{array}{r}\text { economic } \\
\text { benefitC }_{3} \\
0.1805 \\
\end{array}$} & Per capita GDPD $7\left(\right.$ Yuan • person $\left./^{-1}\right)$ & 0.0469 & 8 \\
\hline & & & GDP growth rate $\mathrm{D}_{8} / \%$ & 0.0745 & 4 \\
\hline & & & average salary of staff $\mathrm{D}_{9} /$ Yuan & 0.0591 & 7 \\
\hline & \multirow{5}{*}{$\begin{array}{l}\text { Urbanizat } \\
\text { ion level } \\
\mathrm{B}_{2} \\
0.2808\end{array}$} & \multirow{2}{*}{$\begin{array}{l}\text { population } \\
\text { stateC }_{4} \\
0.1872 \\
\end{array}$} & density of population $\mathrm{D}_{10}\left(\right.$ person $\left.\bullet / \mathrm{km}^{-2}\right)$ & 0.1248 & 2 \\
\hline & & & natural population growth rate $\mathrm{D}_{11 /} \%$ & 0.0624 & 6 \\
\hline & & \multirow{3}{*}{$\begin{array}{l}\text { Living } \\
\text { standard } \\
\mathrm{C}_{5} \\
\quad 0.0940 \\
\end{array}$} & per capita disposable income $\mathrm{D}_{12} / \mathrm{Yuan}$ & 0.0464 & 9 \\
\hline & & & $\begin{array}{l}\text { Per capita year-end savings balance } \\
\mathrm{D}_{13} / \text { Yuan }\end{array}$ & 0.0184 & 16 \\
\hline & & & consumer price index $\mathrm{D}_{14 /} \%$ & 0.0292 & 11 \\
\hline & \multirow{8}{*}{$\begin{array}{c}\text { matching } \\
\text { constructi } \\
\text { on } \mathrm{B}_{3} \\
0.1350\end{array}$} & \multirow{4}{*}{$\begin{array}{l}\text { Public } \\
\text { service } \mathrm{C}_{6} \\
\quad 0.0675\end{array}$} & $\begin{array}{l}\text { Number of schools per } 10,000 \mathrm{D}_{15} \\
\left(\text { one } \cdot 10000 \text { persons } /^{-1}\right)\end{array}$ & 0.0244 & 13 \\
\hline & & & $\begin{array}{l}\text { Number of hospital beds per } 10,000 \text { people } \\
\mathrm{D}_{16} / \text { bed }\end{array}$ & 0.0221 & 14 \\
\hline & & & $\begin{array}{l}\text { Number of institutions with cultural } \\
\text { activities per } 10,000 \text { population } \mathrm{D}_{17} \\
\left(\text { institute } \cdot 10000 \text { persons } /^{-1}\right)\end{array}$ & 0.0110 & 19 \\
\hline & & & $\begin{array}{l}\text { Number of public transport vehicles per } \\
10,000 \text { population } D_{18} \quad \text { (vehicle } \cdot 10000 \\
\text { persons } /^{-1} \text { ) }\end{array}$ & 0.0100 & 20 \\
\hline & & \multirow{4}{*}{$\begin{array}{c}\text { Environme } \\
\text { nt state } C_{7} \\
0.0675\end{array}$} & $\begin{array}{l}\text { green coverage rate of developed areas } \\
\mathrm{D}_{19 / \%}\end{array}$ & 0.0180 & 17 \\
\hline & & & $\begin{array}{l}\text { per capita green area } \mathrm{D}_{20}(/ \mathrm{hm} 2 \cdot 10000 \\
\left.\text { persons }^{-1}\right)\end{array}$ & 0.0307 & 10 \\
\hline & & & sewage treatment rate $\mathrm{D}_{21} / \%$ & 0.0095 & 21 \\
\hline & & & $\begin{array}{l}\text { Harmless disposal rate of domestic waste } \\
\mathrm{D}_{22} / \%\end{array}$ & 0.0095 & 21 \\
\hline
\end{tabular}

This index can be used to evaluate development state and improvement degree of city function construction, it makes linear weight calculation by giving weight to every index and making standardized processing, it can get the final result. The calculation formula is as follows: $C C R H=\sum_{i=1}^{n} W j U j,(i=1,2, \ldots, n)$. In the formula, CCRH is development index of production-city integration; $U_{\mathrm{j}}$ respectively represents economic development index, urbanization level index and matching construction index. $\mathrm{W}_{\mathrm{j}}$ is weight corresponds to every index. Compared with city construction experiences both in China and abroad, it designs evaluation index standard of Chinese production-city integration according to calculation route of this paper at the same time: $0.2 \sim 0.4$ is basic separation pattern, $0 \sim 0.2$ is highly integration pattern, $0.6 \sim 0.8$ is medium 
integration pattern, we can make clear city development stage and pointedly plan city development key points by comparing with development index of production-city integration.

\section{Conclusions}

This paper constructs production-city integration measurement system composed of urbanization index, industrialization index and separation index by learning lessons from coordinated, integration development measurement research result of industrialization and urbanization, of which, urbanization index is not restricted by population urbanization, while it introduces into aspects and factors such as environmental protection and safety etc, measurement system must be complete and scientific. Finally, it uses factor analysis to obtain the main factors of affecting production-city degree, so it further makes cluster analysis on production-city integration level of hi-tech areas in Chinese major cities, so it gets grade classification. This paper constructs production-city evaluation model of city, makes qualitative and quantitative analysis, gets effect factors and its sequence of production-city integration, constructs development index and its evaluation standard of production-city integration, provides reference ideas and methods on production-city integration construction. At present stage, there are many cities in China are actively expanding city development space, expect to relieve population and employment pressure in main cities by constructing development area, new towns etc, which has actual referential meanings for planning and development of new town. Every city is in gradual planning and construction, there are many factors affecting production-city integration, we should make proper adjustment according to actual conditions of cities, enhance science and reliability of evaluation result. On calculating weight index, we can combine with other methods to comprehensively provide weight, gradually improve evaluation methods, so that it can make more effective evaluation on production-city integration.

\section{References}

[1]Shen Zhengping, Chen Weibo. New Channels of New Town Production-city Integration [J]. China Ancient City, 2015, 10:30-36.

[2]Su Lin, Guo Bing, Li Xue. Research on Fuzzy Level Comprehensive Evaluation on Production-city Integration in Hi-tech Zone Park- - Take Hi-tech Park Zone of Shanghai for Example [J]. Industrial Technology Economics, 2013, 07:12-16.

[3]Shi Yishao. Research on Production-city Integration: Review and New Exploration [J]. Urban Planning Forum, 2016, 05:73-78.

[4]Fang Chuanglin, Wang Shaojian, Wang Yang. Low -carbon and Ecological New Town in China: State, Problem and Countermeasure [J]. Geography Research, 2016, 09:1601-1614.

[5]Fu Daishan, Fu Jing. Production-city Integration Degree Test Based on Fuzzy - level Comprehensive Evaluation Method_—-Take Shenyang Economic Area for Example [J]. Journal of Shenyang University of Technology (social science edition), 2015, 05:425-435. 